East African Medical Journal Vol. 86 No. 10 October 2009

PRESENTATION AND MANAGEMENT OF CERVICOFACIAL NECROTISING FASCIITIS: REPORT OF NINE CASES

K.J. Koech, BDS, MDS, Oral and Maxillofacial Surgeon, Department of Dentistry, Kenyatta National Hospital, P.O. Box 19552-00202, Nairobi, Kenya and M.L. Chindia, BDS, MSc, FFDRCS, Associate Professor, Department of Oral and Maxillofacial Surgery, Oral Pathology and Oral Medicine, School of Dental Sciences, University of Nairobi, P.O. Box 19676- 00202, Nairobi, Kenya

Request for reprints to: Dr. K. J. Koech, Department of Dentistry, Kenyatta National Hospital, P. O. Box 19552-00202, Nairobi, Kenya

\title{
PRESENTATION AND MANAGEMENT OF CERVICOFACIAL NECROTISING FASCIITIS: REPORT OF NINE CASES
}

\author{
K. J. KOECH and M.L. CHINDIA
}

\begin{abstract}
SUMMARY
Cervicofacial necrotising fasciitis (CNF) is an acute soft tissue infection that primarily involves the subcutaneous, adipose and fascial planes of the head and neck region. Secondary ischaemia of the skin results in widespread ulceration and suppuration. It is imperative that early diagnosis is made and judicious medical and surgical intervention instituted. We present a case series of patients with CNF diagnosed and managed at the division of oral and maxillofacial surgery of the Kenyatta National Hospital in Kenya.
\end{abstract}

\section{INTRODUCTION}

Cervicofacial necrotising fasciitis (CNF) which has been referred to as the flesh eating disease' is a rapidly progressive, spreading inflammatory process which is located in the deep fascia with secondary necrosis of the subcutaneous tissues (1). The occurrence of this condition in the head and neck region is uncommon; and specifically in the face, it is an extremely rare condition $(2,3)$. In its early stages $\mathrm{CFN}$ maybe readily mistaken for less serious and more frequent soft tissue infections including erysipelas and folliculitis. Early diagnosis and prompt medical and surgical intervention are crucial to avoid the devastating consequences of this severe soft tissue bacterial infection (4). It must be emphasised that there is a direct relationship between morbidity, mortality and the time lapse before the start of appropriate treatment (5).

Systemic conditions such as uncontrolled diabetes mellitus, renal disease, cardiovascular disorders, peripheral vascular disease, cirrhosis and obesity may predispose individuals to CNF (6). We present a case series of CNF in a tropical setting.

\section{CASE REPORTS}

This was a clinical audit of patients who presented with salient features of CNF during the periods
January 2004 to August 2008. The clinical parameters which were recorded as the cases presented and were managed included thebio-data, comprehensive clinical features and the mode of medical and surgical intervention. The duration of hospital stay was also documented accordingly.

There were four female and five male patients reviewed during this period whose ages ranged from three months to sixty years. One of the patients (Figure 1) presented with submandibular cellulitis following extraction of a mandibular molar at an unregistered clinic in a low income residential area. Despite being on intravenuus antibiotic therapy he subsequently developed CNF while in hospital and which progressively spread to involve the sacral region. Surprisingly, a microbiological examination and culture that was done during the progressive stage of the disease was negative for bacteria. The rest of the patients presented with established infection with variable involvement of the submandibular region, the scalp face and the neck. The causes of infection included odontogenic sources in five of the patients while suspected skin infections in the neck creases was seen in the babies (Figures 2 and 3 ). Uncontrolled diabetes was identified as a co-morbid condition in two of the patients while two patients were diagnosed at presentation with the human immunodeficiency virus (HIV) infection. 
Figure 1

Incision sites of necrotising fasciitis extending to the sacral region

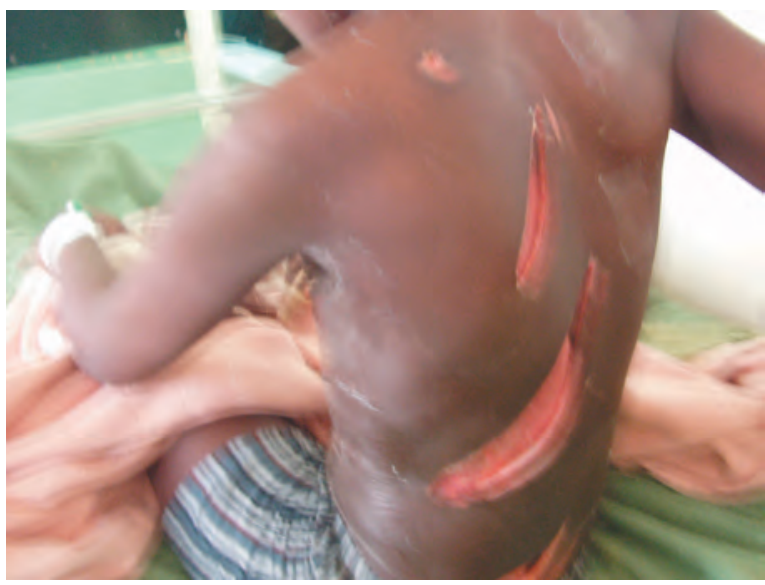

Figure 2

Presentation of CNF in a one-year-old child

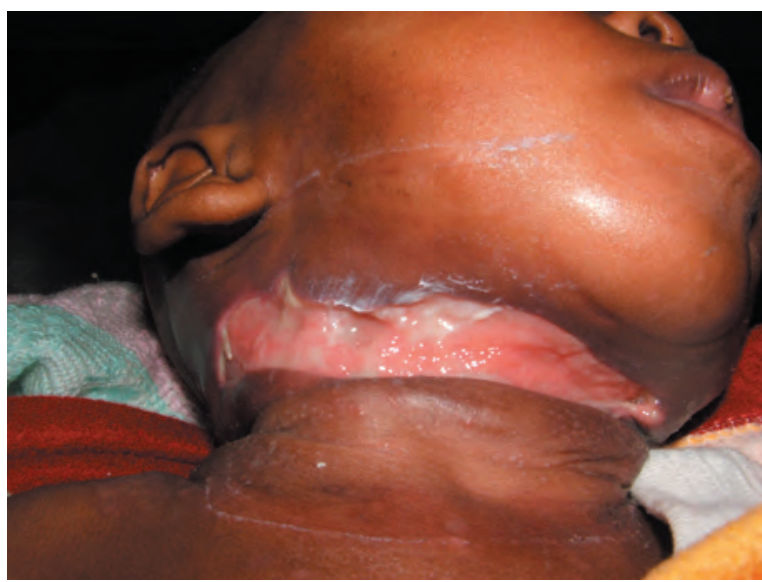

Figure 3

Presentation of CNF in a three-month-old baby

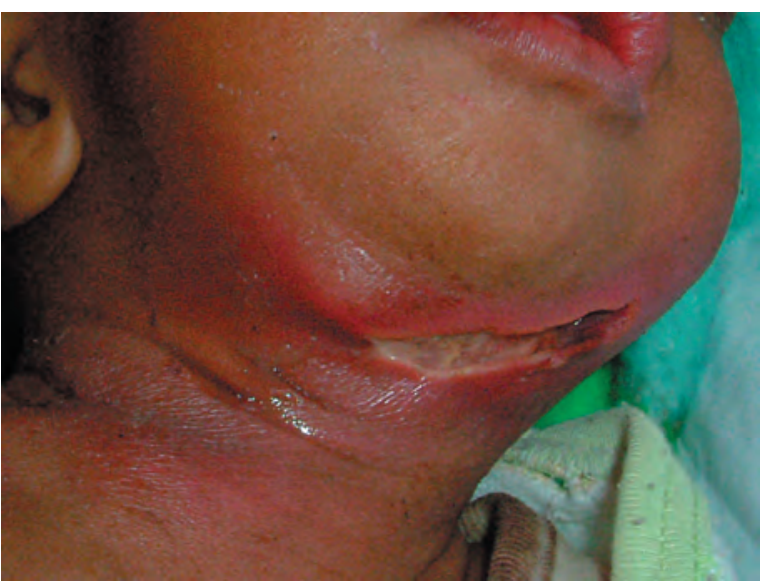

Figure 4

Clinical appearance in an elderly patient

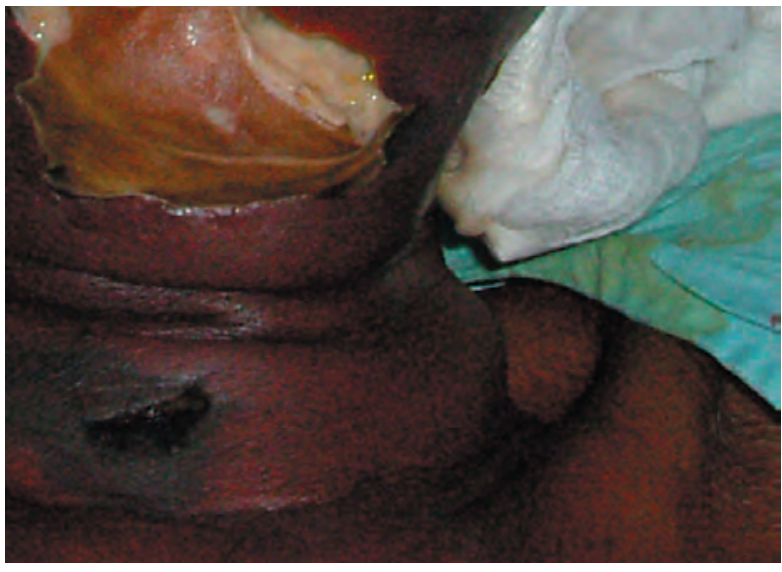

Table 1

Clinical status of nine patients with cervicofacial necrotising fasciitis

\begin{tabular}{|c|c|c|c|c|c|c|}
\hline $\begin{array}{l}\text { Case } \\
\text { No. }\end{array}$ & Sex/Age & Aetiology & Sites involved & $\begin{array}{l}\text { Concomitant } \\
\text { illness }\end{array}$ & Hospitalisation & $\overline{\text { Outcome }}$ \\
\hline 1 & $\mathrm{~F} / \mathrm{l}$ & Skin & Submandibular & None & 1 week & Good \\
\hline 2 & $\mathrm{M} / 28$ & Odontogenic & $\begin{array}{l}\text { Submandibular/ } \\
\text { neck/ chest }\end{array}$ & Diabetes mellitus & 4 weeks & Good \\
\hline 3 & $\mathrm{M} / 35$ & Odontogenic & $\begin{array}{l}\text { Submandibular/ } \\
\text { neck }\end{array}$ & None & 4 weeks & Good \\
\hline 4 & $\mathrm{M} / 45$ & Odontogenic & $\begin{array}{l}\text { Scalp, temporal } \\
\text { region and face }\end{array}$ & HIV & 3 weeks & Fatal \\
\hline 5 & $\mathrm{~F} / 50$ & Odontogenic & $\begin{array}{l}\text { Scalp, temporal } \\
\text { region }\end{array}$ & Diabetes mellitus & 3 weeks & Fatal \\
\hline 6 & $\mathrm{~F} / 60$ & Unknown & $\begin{array}{l}\text { Submandibular/ } \\
\text { neck }\end{array}$ & $\begin{array}{l}\text { Malnutrition and } \\
\text { anaemia }\end{array}$ & 4 weeks & Good \\
\hline 7. & $\mathrm{~F} / 4$ months & Skin & $\begin{array}{l}\text { Submandibular/ } \\
\text { neck }\end{array}$ & HIV & 4 weeks & Good \\
\hline 8 & $\mathrm{M} / 3$ months & Skin & $\begin{array}{l}\text { Submandibular/ } \\
\text { neck }\end{array}$ & Unknown & 3 weeks & Good \\
\hline 9. & $\mathrm{M} / 23$ & Odontogenic & $\begin{array}{l}\text { submandibular/ } \\
\text { neck/back/ } \\
\text { sacral region }\end{array}$ & None & 3 weeks & Good \\
\hline
\end{tabular}


One of the babies had presumably acquired HIV infection from the mother who was living with HIV/AIDS. Despite this unfortunate scenario the baby responded well to her management. The oldest patient (Figure 4) was debilitated and malnourished; and had anaemia with a haemoglobin concentration of $6 \mathrm{gm} / \mathrm{dl}$ and required blood transfusion. Aggressive repeated surgical debridement, broad spectrum antibiotic therapy and fluid therapy were instituted and management of diabetes mellitus was carried out in the patients who manifested the co-morbid condition. After a period of treatment, three of the patients had split thickness skin grafts with good results.

Despite aggressive treatment, two of the patients, one with uncontrolled diabetes mellitus and another with HIV infection succumbed to the disease. As at the time of writing this paper two of the patients were still undergoing treatment at the hospital. Table 1 illustrates the various bio-data and the salient clinical parameters of the patients.

\section{DISCUSSION}

The term necrotising fasciitis, which was coined by Wilson in 1952, had, gained wide acceptance because it aptly emphasizes the widespread necrosis of the fascia that is a consistent feature of the disease (5). Throughout the decades, what remains intriguing is the mechanism by which this severe bacterial infection largely affects the fascial tissues. It has been well documented that this condition arises from a mixed bacterial infection such that the diverse array of toxins damage tissue structures as happens in NOMA (gangrenous stomatitis). The destructive toxins and cytokines in necrotising fasciitis appear to target fascia and adipose tissue almost exclusively. Skin damage occurs only after its nutritive pathways have been grossly damaged.

While diverse immuno-compromising factors have been implicated in the predisposition to necrotising fasciitis generally, dental infections are considered to be the most common in $50 \%$ of the cases of CNF (7) as was seen in five of the patients presented in this series. However, the children who are presented in this series did not have dental infections; in fact two were babies whose primary teeth had not erupted and we suspected infections from neck skin creases. This finding has hardly been documented in the literature. One of the patients who had a fatal outcome had HIV infection. Interestingly HIV infection/ AIDShas rarely been documented as a direct predisposing factor of $\mathrm{CNF}$ even in cases with very poor oral health. This in essence underscores the intricate pathogenetic mechanisms attendant in this condition. Two of the patients had uncontrolled diabetes mellitus with one of them having been diagnosed for the first time at presentation. Although diabetes mellitus has been attributed as a risk factor in the development of CNF the pathogenesis of the condition in diabetes is unknown. It is worthy noting that even in the absence of predisposing factors, $\mathrm{CNF}$ may be precipitated by routine procedures including third molar extractions (8) and tonsillectomy (9) in healthy individuals underscoring the fact that the aetiology and pathogenesis of the disease is still poorly understood.

Although CNF is a rare condition it presents major management challenges and can run an unpredictable course which may lead to mortality. Aggressive surgical and medical management while identifying and controlling co-morbid conditions remain the mainstay in the management of CNF. Tissue loss in the head and neck region results in cosmetic and functional deformities which often require reconstruction.

\section{ACKNOWLEDGEMENTS}

To the administration of the Kenyatta National Hospital for permission to publish this audit and to Ms. E. Okelo for secretarial services.

\section{REFERENCES}

1. Hotlweg-Majert, H., Weyer, N., Metzger, M.C. and Ishon, R. Cervicofacial necrotizing fasciitis. Diabetics Res. Clin. Practice. 2006; 72:206- 208.

2. Benavides, G., Blanco, P. and Pinedo, R. Necrotizing fasciitis of the face A report of one successfully treated case. Otolaryngol. Head Neck Surg. 2003; 128: 894- 896.

3. Caballero, M., Sabater, F.,Traqserra, J. et al. Epiglottitis and necrotizing fasciitis: Alife threatening complication of infectious mononucleosis. Acta Otolaryngol. 2005; 12: 1130-1133.

4. Djupesland per, G. Necrotizing fasciitis of the head and neck-report of three cases and review of the literature. Acta Otolaryngol. 2000; (Supp1.)543:186-189.

5. Obiechina, A.E., Arotiba, J.T., and Fasola, A.O. Necrotising fasciitis of odontongenic origin in Ibadan, Nigeria. Brit. J. Oral Maxillofacial Surg. 2001; 39: 122-126.

6. Whitesides, L., Cotto-Cumba, C. and Myers, R.A.M. Cervical necrotising fasciitis of odontogenic origin: Acase report and review of 12 cases. J. Oral Maxillofac. Surg. 2000; 58: 144-151.

7. Marioni, G., Rinaldi, R., Ottaviano, G., et al. Cervical necrotizing fasciitis: A novel clinical presentation of Burkholderia Cepacia infection. J. Infect. 2006; 53: 219-222.

8. Recalde, P., Engroff, S.H., Jansisyanont, P. and Ord, R.A. Paediatric necrotizing fasciitis complicating third molar extraction: report of a case. Inter. J. Oral Maxillofac. 2004; 33:411-414.

9. Sonne, J., Kim, S.B. and Frank, D.K. Cervical necrotizing fasciitis as a complication of tonsillectomy. Otolaryngol Head Neck Surg. 2001; 125: 670-672. 